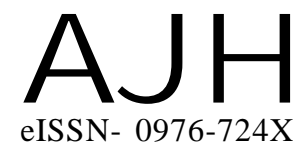

Article history :

Received : 22.06.2017

Revised : 12.11.2017

Accepted : 19.11 .2017

Members of the Research Forum

Associated Authors:

${ }^{1}$ Department of Floriculture and

Landscaping, Punjab Agricultural

University, LUDHIANA (PUNJAB)

INDIA

Author for correspondence :

TANYA THAKUR

Department of Floriculture and Landscaping, Punjab Agricultural University, LUDHIANA (PUNJAB) INDIA

Email : tanyathakurflori@gmail.com
THEASIAN JOURNALOF HORTICULTURE

Volume 12 | Issue 2 | December, 2017 | 230-233

Visit us -www.researchjournal.co.in

\title{
Standard nitrogen application for chrysanthemum cultivar Snowball
}

\section{TANYA THAKUR AND H.S. GREWAL ${ }^{1}$}

ABSTRACT : The experiment was conducted to standardize the nitrogen application for the standard potted Chrysanthemum morifolium cultivar Snowball, during the year 2015-16 in Ludhiana.The nitrogen (as urea) was applied twice in mid-September and mid-October, in six different treatments i.e. control, $100 \mathrm{mg} /$ pot, $200 \mathrm{mg} /$ pot, $300 \mathrm{mg} /$ pot, $400 \mathrm{mg} / \mathrm{pot}$ and $500 \mathrm{mg} /$ pot. The different levels of nitrogen doses had significant $(\mathrm{p}<0.05)$ effect on the vegetative growth and flowering, however, the application of $500 \mathrm{mg} /$ poturea gave maximum plant height $(73.03 \mathrm{~cm})$, number of leaves $(31.02)$, root suckers per plant $(12.10)$, flower size $(17.67 \mathrm{~cm})$ and delayed flower bud appearance, colour break stage and full bloom $(70.55,85.17$ and 115.28 days, respectively), however, deteriorated flower quality with respect to reduced flowering duration (6.15 days). Therefore, it was concluded that $300 \mathrm{mg}$ urea/pot applied twice was optimum dose of nitrogen application for quality flower pot production.

KEY WORDS : Chrysanthemum, Nitrogen, Urea, Vegetative growth, Flowering

HOW TO CITE THIS ARTICLE : Thakur, Tanya and Grewal, H.S. (2017). Standard nitrogen application for chrysanthemum cultivar snowball. Asian J. Hort., 12(2) : 230-233, DOI : 10.15740/ HAS/TAJH/12.2/230-233. 